\title{
Effect of intercropping cow pea with pearl millet on forage yield and competitive relationships
}

\author{
Mohamed A. M. E., Ibrahim M. M., El-Said M. A. A., Mahdy A. Y. \\ Department of Agronomy, Faculty of Agriculture, Al-Azhar University (Assiut Branch), Assiut, Egypt
}

\begin{abstract}
A field experiment was conducted at the Agricultural Experimental Farm of the Agriculture Faculty, Al-Azhar University, Assiut, Egypt, during successive summer seasons of 2017 and 2018 to study the effect of intercropping cow pea with pearl millet on forage yield and competitive relationships. A randomize complete block design (RCBD) with three replications was used. Results could be summarized as follows:

- The pure stands of the pearl millet $\left(\mathrm{S}_{1}\right)$ and cow pea $\left(\mathrm{S}_{2}\right)$ produced the maximum total fresh and dry forage yields (ton $/$ fed) $($ fed $=$ feddan $=$ Acre $)$ as compared with the different intercropping systems in both seasons. Meanwhile, the cow pea and pearl millet grown under intercropping system of 2:2 ridges $\left(\mathrm{S}_{5}\right)$ recorded the highest mean values for total fresh and dry forage yields (ton /fed) whereas cow pea intercropped with pearl millet side: side $\left(\mathrm{S}_{3}\right)$ recorded the lowest mean values as compared to the other tested intercropping systems in both seasons.

- Crude protein \% was increased by intercropping system of 2:2 ridges $\left(\mathrm{S}_{5}\right)$ in both seasons compared with the different studied intercropping systems.

- Land equivalent ratio (LER) and relative crowding coefficient (RCC) recorded the highest mean values by intercropping system of 2:2 ridges $\left(\mathrm{S}_{5}\right)$ on the both seasons. Pearl millet was dominant crop and cow pea was dominated crop at all intercropping systems in the both seasons.
\end{abstract}

From the preceding results it be concluded that intercropping cow pea with pearl millet under intercropping system of $2: 2$ ridges $\left(\mathrm{S}_{5}\right)$ caused an increase in forage yield production and its quality as compared to the other studied intercropping systems.

Keywords: intercropping systems, cow pea, pearl millet, forage yield, crude protein.

*Corresponding author: Mohamed A. M. E., 


\section{Introduction}

The production of forage crops is very important for livestock production in Egypt. Farmers and livestock breeders depend for feeding their cattle on corn plants, Sudan grass and sweet sorghum in summer after the end of clover (Berseem) season. Shahin et al. (2013) in Egypt, one of the most important problems for animal production is the reduction in forage crops production during the summer season. So, increasing forage crop production per unit area during the summer season to solve this problem considers the major aim. The increased deficiency of green forage in the summer season in Egypt requires more attention to increase the forage yield of pearl millet and cow pea. This could be achieved in part by sowing grass and legume forage crops in mixture. Pearl millet (Pennisetum glaucum L.) is considered as one of the most important forage crops in many countries of the world due to its high forage yielding potential and good quality. Also, cow pea (Vigna sinensis L.) is a grain legume belonging to the family leguminosae. Its value lies in its high protein content. Cow pea is an important food and forage. Zeidan et al. (2003) sowing grass and legume forage crops in mixture is a better choice to increase the quality of forage and forage yield per unit area. Gawad et al. (1991) indicated that cow pea plant height, number of branches /plant, number of leaves/plant, fresh forage yield and dry forage yield were greater in pure stands than that of sorghum cropping pattern. Also, the land equivalent ratio (LER) of sorghum was greater than that of cow pea cropping pattern. Sherief and Said (1999) stated that intercropping cow pea with sorghum in alternate triple rows produced highest forage yield of the mixture compared with other intercropping systems and solid planting of either sorghum or cow pea, also the land equivalent ratio (LER) of both crops was greater than one in all intercropping systems. Abd El-Shafy (2002) showed that total fresh and dry forage yields when teosinte intercropped with guar were significantly higher than those obtained from guar monoculture, but lower than those obtained from teosinte sole cropping. Zeidan et al. (2003) revealed that the mixture fodder maize (100\% plant population) on both sides of two ridges alternated with cow pea $(50 \%)$ on both sides of other two ridges gave higher fresh and dry forage yields compared with all other mixtures as well as fodder maize, cow pea and guar pure stands, also mixture caused an increase in land equivalent ratio (LER). Ayub et al. (2004) found that the seed proportions of sorghum and rice bean significantly affected the sorghum plant height, number of leaves of sorghum and rice bean plants, green and dry matter yields. Height of rice bean plant and stem diameter of sorghum were not influenced significantly by seed proportions. Girase et al. (2007) showed that pearl millet + moth bean planted 2:1 row ratio recorded maximum land equivalent ratio (LER) 1.47 followed by pearl millet + cow pea 2:1 row ratio 1.39. Abd El-Shafy et al. (2009) stated that forage mixture were of more crude protein (CP) content than teosinte but less than cow pea in its pure stand. The intercropping pattern of 2:2 gave the highest yield advantage and 
caused an increase in land usage of $36 \%$ and $34 \%$ in two respective summer seasons. Dahmardeh et al. (2009) reported that intercropping of maize and cow pea resulted in more crude protein content than maize sole cropping. Sharawy et al. (2011) stated that plant height of teosinte, cow pea and guar decreased significantly by intercropping compared with their pure stands. Total fresh and dry forage yields were significantly reduced by intercropping teosinte with cow pea or guar compared with teosinte as a sole crop. Abusuwar and Bakshawain (2012) reported that intercropping of sudan grass and cow pea significantly increased fresh and dry forage yields, improved forage quality $(\mathrm{CP} \%)$ and land equivalent ratio (LER). Ibrahim et al. (2012) found that all monoculture legumes (cluster bean, cow pea and sesbania) produced highest CP percentage than their mixtures with maize. El-Sarag (2013) indicated that mixing ratio of 1:1 cow pea / sorghum $(\mathrm{C} / \mathrm{S})$ is surpassed pure stand and all other ratios (1:2 and 1:3) in plant height for both plants at the three cuts. Cow pea gave more number of leaves with pure stand than any mixing ratios followed by $1: 1 \mathrm{C} / \mathrm{S}$ ratio at the three studied cuts. While sorghum number of leaves responded non - significantly to forage mixing ratio at all cuts except the third one, as the 1:2 C/S ratio gave the maximum number of leaves. Refay et al. (2013) indicated that sorghum plants intercropped with cow pea (2:2 rows) recorded higher values of plant height, number of leaves/plant, stem diameter and leaf area/plant. Hamd Alla et al. (2014) indicated that fresh and dry forage yields of cow pea were lower in intercropping with maize than sole. Suryawanshi et al. (2014) found that plant height at the time of harvest in both crops, green forage yield, dry matter yield and crude protein were recorded higher under treatment maize + cow pea (2:1). Abd ElLateef et al. (2015) showed that the highest land equivalent ratio (LER) value for maize - cow pea was reported with 2:4 intercropping pattern. Abdoul Karim et al. (2016) found that the ratio line $1: 1$ and 1:2 (millet: cow pea) had no significant effect on the number of tillers $/ \mathrm{m}^{2}$ of millet, but had significant effected on fodder dry matter yield. The fodder yield was higher in ratio 1:2 than in ratio 1:1. Hassan et al. (2017) resulted that the pure stand of pearl millet gave higher total fresh and dry yields than either sudan grass or teosinte, whereas cow pea pure stand gave higher total fresh and dry forage yields compared with sole planting of either guar or lima bean. Results also confirmed the superiority of pearl millet + cow pea intercropping in total fresh and dry forage yields over pure legumes and all other intercropping patterns, as well as resulted that the planting of grasses intercropped with legumes caused increase in land equivalent ratio (LER) for the total three cuts of both crops which was greater than one in all intercropping treatments. Mahfouz et al. (2017) showed that, the maximum significant values of aggresivity (A) for rye grass crop was found in pattern ratio of 2 ryes: 1 fenugreek in the both seasons. The highest total land equivalent ratio (LER) was obtained by sowing the crops in the intercrop ratio of $2: 1$ and the lowest total LER obtained by sowing the crops in the intercrop ratio of 1:1 in both seasons. 
Salem et al. (2019) revealed that intercropping pattern of 2:2 recorded the highest values for fresh and dry forage yields whereas cow pea intercropped on the other side gave the lowest values in the both seasons. Crude protein percentage was increased by different intercropping pattern. Also land equivalent ratio (LER) and relative crowding coefficient (RCC) recorded the highest values by interaction between 2:2 ridges and $75 \%$ teosinte $+50 \%$ cow pea seeding rates of its pure stands in both seasons. Teosinte was dominant crop in 6 out of 9 treatments in both seasons. The main objective of this work was to study the effect of intercropping cow pea with pearl millet on forage yield and competitive relationships under Assiut governorate conditions, Egypt.

\section{Materials and methods}

A field experiment was conducted at the Agricultural Experimental Farm of the Agriculture Faculty, Al-Azhar University, Assiut governorate, Egypt, during 2017 and 2018 seasons to study the effect of intercropping cow pea with pearl millet on forage yield and competitive relationships under Assiut governorate conditions.

\subsection{Soil analysis}

Some physical and chemical properties of the experimental site soil were analyzed according to the methods described by Black (1965) for available nitrogen, Jackson (1973) for $\mathrm{pH}$, organic matter and EC, Olsen and Sommers (1982) for available phosphorus had presented in Table (1).

\subsection{The used treatments}

The used treatments were as follows:

- Pure stand of pearl millet using planting distance of $20 \mathrm{~cm}$ between hills on both sides of the ridge $(100 \%$ plant population), with a seeding rate of $18 \mathrm{Kg} / \mathrm{fed},\left(\mathrm{S}_{1}\right)$ (fed = feddan $=$ Acre).

- Pure stand of cow pea using planting distance of $20 \mathrm{~cm}$ between hills on both sides of the ridge $(100 \%$ plant population), with a seeding rate of 20 $\mathrm{Kg} / \mathrm{fed},\left(\mathrm{S}_{2}\right)$.

- Planting pearl millet on one side of the ridge using planting distance of $20 \mathrm{~cm}$ between hills $(50 \%$ plant population), with a seeding rate of 9 $\mathrm{Kg} / \mathrm{fed}$, and cow pea on the other side of the ridge using planting distance of $20 \mathrm{~cm}$ between hills (50\% plant population), with a seeding rate of $10 \mathrm{Kg} / \mathrm{fed},\left(\mathrm{S}_{3}\right)$.

- Planting pearl millet on both sides of the ridge using planting distance of $20 \mathrm{~cm}$ between hills $(50 \%$ plant population), with a seeding rate of 9 $\mathrm{Kg} / \mathrm{fed}$, and cow pea on both sides of the other ridge, alternatively, using planting distance of $20 \mathrm{~cm}$ between hills (50\% plant population), with a seeding rate of $10 \mathrm{Kg} / \mathrm{fed},\left(\mathrm{S}_{4}\right)$.

- Planting pearl millet on both sides of two ridges using planting distance of 
$20 \mathrm{~cm}$ between hills $(50 \%$ plant population), with a seeding rate of 9 $\mathrm{Kg} / \mathrm{fed}$, and cow pea on both sides of the other two ridges, alternatively, using planting distance of $20 \mathrm{~cm}$ between hills (50\% plant population), with a seeding rate of $10 \mathrm{Kg} / \mathrm{fed}$, $\left(\mathrm{S}_{5}\right)$.

\subsection{Experimental design}

A randomize complete block design (RCBD) with three replications was used. The plot area was $16.2 \mathrm{~m}^{2}$ included 8 ridges, each $3.0 \mathrm{~m}$ length and $0.6 \mathrm{~m}$ wide. Sowing dates of both crops were on June 10 at the two seasons. Grains of pearl millet variety Shandaweel 1 and seeds of cow pea variety (Balady) were provided by the Forage Research Division, Field Crops Research Institute, Ministry of Agricultural and Land Reclamation, Giza, Egypt. The preceding winter crop was wheat (Triticum aestivum L.) in the both seasons. Calcium superphosphate $\left(\begin{array}{lll}15.5 \% & \mathrm{P}_{2} \mathrm{O}_{5}\end{array}\right)$ was added before sowing at the rate 150 $\mathrm{Kg} / \mathrm{fed}$., and nitrogen fertilizer was added as ammonium nitrate $(33.5 \% \mathrm{~N})$ at the rate of $60 \mathrm{Kg} \mathrm{N} / \mathrm{fed}$., was applied in two equal doses, where the first one was applied after 15 and 30 days (half and half) and the second was applied after the first cut. The two cuts were taken in the both seasons, the first cut was after 40 days from sowing date and the second cut was after 80 days from sowing date in the both seasons.

Table (1): The physical and chemical analysis of the experimental soil.

\begin{tabular}{|c|c|c|c|c|c|}
\hline Characteristics & \multicolumn{2}{|c|}{ Seasons } & Characteristics & \multicolumn{2}{|c|}{ Seasons } \\
\hline Physical analysis & 2017 & 2018 & Chemical analysis & 2017 & 2018 \\
\hline Sand (\%) & 28.42 & 29.55 & Organic matter $(\%)$ & 1.07 & 0.96 \\
\hline Silt (\%) & 37.35 & 37.00 & Available N (ppm) & 76.30 & 73.45 \\
\hline Clay (\%) & 34.23 & 33.45 & Available P (ppm) & 9.66 & 9.30 \\
\hline \multirow{4}{*}{ Soil texture } & \multirow{4}{*}{\multicolumn{2}{|c|}{ Clay loam }} & Available K (ppm) & 375.39 & 345.62 \\
\hline & & & $\mathrm{pH}\left(\mathrm{sp} \cdot \mathrm{m}^{-1}\right)$ & 7.83 & 7.91 \\
\hline & & & E.C. $\left(\right.$ ds. $\left.\mathrm{m}^{-1}\right)$ & 1.15 & 1.11 \\
\hline & & & Total $\mathrm{CaCo}_{3}(\%)$ & 2.62 & 2.44 \\
\hline
\end{tabular}

\subsection{Studied characters}

\subsubsection{Vegetative characters}

\subsubsection{Vegetative characters}

For pearl millet:

- Plant height $(\mathrm{cm})$.

- Number of leaves /plant.

- Number of tillers /plant.
- Leaf area /plant $\left(\mathrm{cm}^{2}\right)$, was calculated using the following formula: Leaf area $=$ maximum leaf length $\mathrm{x}$ maximum leaf width 0.75 as out lined by Stickler et al. (1961).

For cow pea:

- Plant height $(\mathrm{cm})$. 
- Number of leaves /plant.

- Number of branches /plant.

- Leaf area /plant $\left(\mathrm{cm}^{2}\right)$ by disk method which recommended by Johanson (1967) that used the following formula: Bald area = ((Total dry weight of blades per plant) $\mathrm{x}$ (A known area of disk sample)) / (Dry weight of the same disk sample).

\subsubsection{Fresh and dry forage yield in each} cut and total

At cutting time an area of $7.2 \mathrm{~m}^{2}$ was cut (four inner ridges, $3.0 \mathrm{~m}$ long) and fresh forage yield/fed., for each crop as well as for both components in case of intercropped was calculated. Samples of $250 \mathrm{~g}$ fresh forage were oven dried at $70^{\circ} \mathrm{C}$ up to constant weight and dry forage yield ton /fed, was calculated.

\subsubsection{Crude protein percentage}

Crude protein percentage (CP \%): total nitrogen content was determined by using the modified Kjeldahl method according to the A.O.A.C. (1980), crude protein was calculated by multiplying the total nitrogen by 5.75 for pearl millet and 6.25 for cow pea.

\subsubsection{Competitive relationships}

\subsubsection{Land equivalent ratio}

Land equivalent ratio (LER) was calculated according to Willey (1979) by the following formula:

$$
\text { LER }=\frac{Y_{a b}}{Y_{a a}}+\frac{Y_{b a}}{Y_{b b}}
$$

Where: $Y_{a a}=$ Pure stand yield of a (pearl millet). $Y_{b b}=$ Pure stand yield of $\mathrm{b}$ (cow pea). $Y_{a b}=$ Yield of intercrop a (pearl millet) with $\mathrm{b}$ (cow pea). $Y_{b a}=$ Yield of intercrop $b$ (cow pea) with a (pearl millet).

\subsubsection{Relative crowding coefficient}

Relative crowding coefficient (RCC) was calculated according to De Wit (1960) by the following formula:

$$
\begin{gathered}
\mathrm{K}_{\mathrm{ab}}=\frac{Y_{a b \times Z_{b a}}}{\left(Y_{a a}-Y_{a b}\right) \times Z_{a b}} \\
\mathrm{~K}_{\mathrm{ba}}=\frac{Y_{b a \times Z_{a b}}}{\left(Y_{b b}-Y_{b a} \times Z_{b a}\right.} \\
\operatorname{RCC}(\mathrm{K})=\mathrm{K}_{\mathrm{ab}} \times \mathrm{K}_{\mathrm{ba}}
\end{gathered}
$$

Where: $Z_{a b} \%=$ Area occupied by a (pearl millet) with $\mathrm{b}$ (cow pea). $Z_{b a} \%=$ Area occupied by $b$ (cow pea) with a (pearl millet).

\subsubsection{Aggressivity}

Aggressivity (A) was calculated according to Mc-Gilchrist (1965) by the following formula:

$$
\begin{aligned}
& \mathrm{A}_{\mathrm{ab}}=\frac{Y_{a b}}{Y_{a a} \times Z_{a b}}-\frac{Y_{b a}}{Y_{b b} \times Z_{b a}} \\
& \mathrm{~A}_{\mathrm{ba}}=\frac{Y_{b a}}{Y_{b b} \times Z_{b a}}-\frac{Y_{a b}}{Y_{a a} \times Z_{a b}}
\end{aligned}
$$

\subsection{Statistical analysis}

The results were statistically analyzed 
according to Gomez and Gomez (1984) using the computer MSTAT-C statistical analysis package by Freed et al. (1989). The least significant differences (LSD) test at probability level of 0.05 was manually calculated to compare the differences among means.

\section{Results and Discussion}

\subsection{Vegetative characters}

\subsubsection{Plant height}

Result presented in Table (2) observed that plant height of pearl millet was significantly affected by intercropping systems at $1^{\text {st }}$ and $2^{\text {nd }}$ cuts in 2017 and
2018 seasons. The intercropping system of 2:2 ridges $\left(\mathrm{S}_{5}\right)$ showed the highest values at $1^{\text {st }}$ and $2^{\text {nd }}$ cuts in both seasons. But plant height of cow pea not significant affected by intercropping systems at $1^{\text {st }}$ and $2^{\text {nd }}$ cuts in both seasons. These results may be due to the intercropping system of 2:2 ridges $\left(\mathrm{S}_{5}\right)$ were able to complement each other in growth integration and reduce intraspecific competition between pearl millet and cow pea plants than other intercropping systems. These results agree with those obtained by Gawad et al. (1991), Ayub et al. (2004), Sharawy et al. (2011), El-Sarag (2013) and Refay et al. (2013).

Table (2): Plant height $(\mathrm{cm})$ of pearl millet and cow pea as influenced by intercropping systems at $1^{\text {st }}$ and $2^{\text {nd }}$ cuts in 2017 and 2018 seasons.

\begin{tabular}{|l|c|c|c|c|c|c|c|c|}
\hline \multirow{3}{*}{$\begin{array}{l}\text { Intercropping } \\
\text { Systems }\end{array}$} & \multicolumn{9}{|c|}{ Plant height $(\mathrm{cm})$} \\
\cline { 2 - 9 } & \multicolumn{4}{|c|}{$1^{\text {st }}$ Cut } & \multicolumn{4}{c|}{$2^{\text {nd }}$ Cut } \\
\cline { 2 - 9 } & 2017 & 2018 & 2017 & 2018 & 2017 & 2018 & 2017 & 2018 \\
\hline $\mathrm{S}_{1}$ & 136.33 & 135.68 & $\ldots \ldots$ & $\ldots \ldots$ & 145.31 & 142.75 & $\ldots \ldots$ & $\ldots \ldots$ \\
\hline $\mathrm{S}_{2}$ & $\ldots \ldots$ & $\ldots \ldots$ & 56.66 & 57.67 & $\ldots \ldots$ & $\ldots \ldots$ & 56.00 & 58.28 \\
\hline $\mathrm{S}_{3}$ & 140.66 & 138.23 & 59.33 & 59.50 & 146.34 & 144.68 & 58.00 & 59.66 \\
\hline $\mathrm{S}_{4}$ & 143.00 & 141.37 & 60.75 & 62.68 & 149.12 & 147.25 & 59.33 & 62.00 \\
\hline $\mathrm{S}_{5}$ & 150.67 & 147.44 & 63.34 & 64.00 & 157.58 & 153.30 & 61.50 & 63.25 \\
\hline $\mathrm{F}-$ test & $*$ & $*$ & N.S & N.S & $*$ & $*$ & N.S & N.S \\
\hline LSD at $5 \%$ & 5.42 & 5.23 & $\ldots \ldots$ & $\ldots$. & 3.59 & 2.84 & $\ldots \ldots$ & $\ldots$. \\
\hline
\end{tabular}

$*=$ significant at 0.05 probability level. N.S = non-significant difference. $\mathrm{S}_{1}=$ pearl millet (pure stand), $\mathrm{S}_{2}=$ cow pea (pure stand), $S_{3}=$ pearl millet : cow pea (side : side), $S_{4}=$ pearl millet : cow pea (1 ridge : 1 ridge), $S_{5}=$ pearl millet : cow pea ( 2 ridges : 2 ridges).

\subsubsection{Number of leaves /plant}

Result presented in Table (3) indicated that number of leaves/plant of pearl millet did not affected significantly by intercropping systems at $1^{\text {st }}$ and $2^{\text {nd }}$ cuts in the both seasons. Data presented in the same Table show that the intercropping systems had a significant effect on the number of leaves/plant of cow pea at $1^{\text {st }}$ and $2^{\text {nd }}$ cuts in the both seasons. Where the highest mean values of the leaves 
number/plant of cow pea were obtained by pure stand $\left(\mathrm{S}_{2}\right)$ at $1^{\text {st }}$ and $2^{\text {nd }}$ cuts in the both seasons. Similar results were obtained by Gawad et al. (1991), Ayub et al. (2004) and El-Sarag (2013).

\subsubsection{Number of tillers or branches/plant of pearl millet or cow pea}

Result presented in Table (4) showed that the number of tillers or branches/plant of pearl millet or cow pea did not affected significantly by intercropping systems at $1^{\text {st }}$ and $2^{\text {nd }}$ cuts in the both seasons. Whatever, the highest mean values of the branches number/plant of cow pea was obtained by intercropping system of $\mathrm{S}_{5}$ at $1^{\text {st }}$ and $2^{\text {nd }}$ cuts in the both season. A similar result was obtained by Abdoul Karim et al. (2016).

Table (3): Number of leaves /plant of pearl millet and cow pea as influenced by intercropping systems at $1^{\text {st }}$ and $2^{\text {nd }}$ cuts in 2017 and 2018 seasons.

\begin{tabular}{|c|c|c|c|c|c|c|c|c|}
\hline \multirow{4}{*}{$\begin{array}{l}\text { Intercroppin } \\
\text { g } \\
\text { Systems }\end{array}$} & \multicolumn{8}{|c|}{ Number of leaves/plant } \\
\hline & \multicolumn{4}{|c|}{$1^{\text {st }} \mathrm{Cut}$} & \multicolumn{4}{|c|}{$2^{\text {nd }} \mathrm{Cut}$} \\
\hline & \multicolumn{2}{|c|}{ Pearl millet } & \multicolumn{2}{|c|}{ Cow pea } & \multicolumn{2}{|c|}{ Pearl millet } & \multicolumn{2}{|c|}{ Cow pea } \\
\hline & 2017 & 2018 & 2017 & 2018 & 2017 & 2018 & 2017 & 2018 \\
\hline $\mathrm{S}_{1}$ & 11.00 & 11.38 & & & 11.42 & 11.33 & & \\
\hline $\mathrm{S}_{2}$ & & 畨 & 23.70 & 23.57 & & ..... & 24.71 & 24.69 \\
\hline $\mathrm{S}_{3}$ & 9.33 & 9.00 & 17.00 & 17.63 & 9.68 & 9.66 & 19.33 & 19.21 \\
\hline $\mathrm{S}_{4}$ & 8.66 & 8.75 & 18.00 & 18.28 & 9.34 & 9.67 & 20.00 & 19.87 \\
\hline $\mathrm{S}_{5}$ & 8.67 & 8.83 & 18.79 & 19.35 & 10.00 & 10.25 & 21.66 & 20.33 \\
\hline $\mathrm{F}$ - test & N.S & N.S & * & $*$ & N.S & N.S & * & * \\
\hline LSD at $5 \%$ & & & 1.63 & 2.08 & & & 3.35 & 3.62 \\
\hline
\end{tabular}

$*$ = significant at 0.05 probability level. $\mathrm{N} . \mathrm{S}=$ non-significant difference. $\mathrm{S}_{1}=$ pearl millet (pure stand), $\mathrm{S}_{2}=$ cow pea (pure stand), $S_{3}=$ pearl millet : cow pea (side : side), $S_{4}=$ pearl millet : cow pea (1 ridge : 1 ridge), $\mathrm{S}_{5}=$ pearl millet : cow pea ( 2 ridges $: 2$ ridges).

Table (4): Number of tillers or branches /plant of pearl millet and cow pea as influenced by intercropping systems at $1^{\text {st }}$ and $2^{\text {nd }}$ cuts in 2017 and 2018 seasons.

\begin{tabular}{|c|c|c|c|c|c|c|c|c|}
\hline \multirow{4}{*}{$\begin{array}{l}\text { Intercroppin } \\
\mathrm{g} \\
\text { Systems }\end{array}$} & \multicolumn{8}{|c|}{ Number of tillers or branches/plant } \\
\hline & \multicolumn{4}{|c|}{$1^{\text {st }} \mathrm{Cut}$} & \multicolumn{4}{|c|}{$2^{\text {nd }} \mathrm{Cut}$} \\
\hline & \multicolumn{2}{|c|}{ Pearl millet } & \multicolumn{2}{|c|}{ Cow pea } & \multicolumn{2}{|c|}{ Pearl millet } & \multicolumn{2}{|c|}{ Cow pea } \\
\hline & 2017 & 2018 & 2017 & 2018 & 2017 & 2018 & 2017 & 2018 \\
\hline $\mathrm{S}_{1}$ & 4.20 & 4.33 & $\ldots \ldots$ & & 4.23 & 4.20 & & \\
\hline $\mathrm{S}_{2}$ & $\ldots \ldots$ & $\ldots \ldots$ & 3.33 & 4.00 & $\ldots \ldots$ & $\ldots \ldots$ & 3.00 & 3.68 \\
\hline $\mathrm{S}_{3}$ & 3.83 & 3.76 & 3.66 & 2.67 & 3.93 & 3.90 & 2.65 & 3.00 \\
\hline $\mathrm{S}_{4}$ & 3.96 & 4.06 & 3.68 & 3.70 & 4.17 & 4.10 & 3.34 & 3.62 \\
\hline $\mathrm{S}_{5}$ & 4.16 & 4.37 & 4.35 & 4.38 & 4.40 & 4.07 & 3.67 & 4.00 \\
\hline $\mathrm{F}$ - test & N.S & N.S & N.S & N.S & N.S & N.S & N.S & N.S \\
\hline LSD at $5 \%$ & $\ldots$ & $\ldots$ & $\ldots$ & $\ldots$ & $\ldots$ & $\ldots$ & $\ldots$ & $\ldots$ \\
\hline
\end{tabular}

N.S = non-significant difference. $S_{1}=$ pearl millet (pure stand), $S_{2}=$ cow pea (pure stand), $S_{3}=$ pearl millet : cow pea (side : side), $S_{4}=$ pearl millet : cow pea (1 ridge : 1 ridge), $S_{5}=$ pearl millet : cow pea ( 2 ridges $: 2$ ridges). 


\subsubsection{Leaf area /plant}

Data presented in Table (5) indicated that Leaf area/plant $\left(\mathrm{cm}^{2}\right)$ of pearl millet was significantly affected by intercropping systems in $2^{\text {nd }}$ cut at the first season only. Data presented in the same Table revealed that the intercropping systems had a significant effect on leaf area /plant $\left(\mathrm{cm}^{2}\right)$ of cow pea at $1^{\text {st }}$ and $2^{\text {nd }}$ cuts in the both seasons. Where the highest mean values of Leaf area/plant $\left(\mathrm{cm}^{2}\right)$ of cow pea was obtained by pure stand $\left(\mathrm{S}_{2}\right)$ at $1^{\text {st }}$ and $2^{\text {nd }}$ cuts in the both seasons. In general, the obtained results are in agreement with this reported by Refay et al. (2013).

\subsection{Fresh and dry forage yield in each cut and total}

Data presented in Table (6) indicated that fresh forage yield (ton /fed) of pearl millet and cow pea were significantly affected by intercropping systems at $1^{\text {st }}$ and $2^{\text {nd }}$ cuts in the both seasons. The intercropping systems of $\mathrm{S}_{1}$ and $\mathrm{S}_{2}$ as pure stand were superior in fresh forage yield (ton /fed) of pearl millet and cow pea. Followed by $2: 2$ ridges $\left(\mathrm{S}_{5}\right)$ at $1^{\text {st }}$ and $2^{\text {nd }}$ cuts in the both seasons. These results are in agreement with those obtained by Gawad et al. (1991), Sherief and Said (1999), Hamd Alla et al. (2014) and Abdoul Karim et al. (2016). Here too, the presented data in Table (7) showed that dry forage yield (ton /fed) of pearl millet and cow pea were significantly affected by intercropping systems at $1^{\text {st }}$ and $2^{\text {nd }}$ cuts in the both seasons. The intercropping systems of $S_{1}$ and $S_{2}$ as pure stand was superior in dry forage yield (ton /fed) of pearl millet and cow pea, respectively followed by $2: 2$ ridges $\left(\mathrm{S}_{5}\right)$ at $1^{\text {st }}$ and $2^{\text {nd }}$ cuts in the both seasons. These results are in harmony with those obtained by Gawad et al. (1991) and Hamd Alla et al. (2014). Data illustrated in Table (8) indicated that total fresh and dry forage yields (ton/fed) were significantly affected by intercropping systems in both seasons.

Table (5): Leaf area /plant $\left(\mathrm{cm}^{2}\right)$ of pearl millet and cow pea as influenced by intercropping systems at $1^{\text {st }}$ and $2^{\text {nd }}$ cuts in 2017 and 2018 seasons.

\begin{tabular}{|l|c|c|c|c|c|c|c|c|}
\hline \multirow{2}{*}{$\begin{array}{l}\text { Intercroppin } \\
\text { g }\end{array}$} & \multicolumn{9}{|c|}{ Leaf area /plant $\left(\mathrm{cm}^{2}\right)$} \\
\cline { 2 - 10 } & \multicolumn{4}{|c|}{$1^{\text {st }}$ Cut } & \multicolumn{4}{c|}{$2^{\text {nd }}$ Cut } \\
\cline { 2 - 9 } & \multicolumn{2}{|c|}{ Pearl millet } & \multicolumn{2}{c|}{ Cow pea } & \multicolumn{2}{c|}{ Pearl millet } & \multicolumn{2}{c|}{ Cow pea } \\
\cline { 2 - 10 } & 2017 & 2018 & 2017 & 2018 & 2017 & 2018 & 2017 & 2018 \\
\hline $\mathrm{S}_{1}$ & 2312.7 & 2317.0 & $\ldots \ldots$ & $\ldots \ldots$ & 2345.2 & 2328.3 & $\ldots \ldots$ & $\ldots \ldots$ \\
\hline $\mathrm{S}_{2}$ & $\ldots \ldots$ & $\ldots \ldots$ & 1757.6 & 1761.3 & $\ldots \ldots$ & $\ldots \ldots$ & 1831.3 & 1803.7 \\
\hline $\mathrm{S}_{3}$ & 2270.2 & 2332.3 & 1317.3 & 1316.3 & 2283.3 & 2349.0 & 1496.3 & 1502.0 \\
\hline $\mathrm{S}_{4}$ & 2296.5 & 2322.0 & 1443.8 & 1444.6 & 2308.7 & 2340.0 & 1546.6 & 1594.2 \\
\hline $\mathrm{S}_{5}$ & 2351.6 & 2374.6 & 1485.7 & 1497.5 & 2418.3 & 2371.7 & 1666.0 & 1619.3 \\
\hline $\mathrm{F}$ - test & N.S & N.S & $*$ & $*$ & $*$ & N.S & $*$ & $*$ \\
\hline LSD at 5\% & $\ldots .$. & $\ldots .$. & 3.73 & 3.59 & 4.61 & $\ldots$. & 3.36 & 3.45 \\
\hline
\end{tabular}

$*$ = significant at 0.05 probability level. N.S = non-significant difference. $\mathrm{S}_{1}=$ pearl millet (pure stand), $\mathrm{S}_{2}=$ cow pea (pure stand), $S_{3}=$ pearl millet : cow pea (side : side), $S_{4}=$ pearl millet : cow pea (1 ridge : 1 ridge), $\mathrm{S}_{5}=$ pearl millet : cow pea ( 2 ridges : 2 ridges). 
Table (6): Fresh forage yield (ton /fed) of pearl millet and cow pea as influenced by intercropping systems at $1^{\text {st }}$ and $2^{\text {nd }}$ cuts in 2017 and 2018 seasons.

\begin{tabular}{|l|c|c|c|c|c|c|c|c|}
\hline \multirow{2}{*}{$\begin{array}{l}\text { Intercroppin } \\
\text { g }\end{array}$} & \multicolumn{9}{|c|}{ Fresh forage yield (ton /fed) } \\
\cline { 2 - 9 } & \multicolumn{9}{|c|}{$1^{\text {st }}$ Cut } & \multicolumn{4}{c|}{$2^{\text {nd }}$ Cut } \\
\cline { 2 - 9 } & \multicolumn{2}{|c|}{ Pearl millet } & \multicolumn{2}{c|}{ Cow pea } & \multicolumn{2}{c|}{ Pearl millet } & \multicolumn{2}{c|}{ Cow pea } \\
\cline { 2 - 9 } & 2017 & 2018 & 2017 & 2018 & 2017 & 2018 & 2017 & 2018 \\
\hline $\mathrm{S}_{1}$ & 29.16 & 29.50 & $\ldots \ldots$ & $\ldots \ldots$ & 30.23 & 29.26 & $\ldots \ldots$ & $\ldots \ldots$ \\
\hline $\mathrm{S}_{2}$ & $\ldots \ldots$ & $\ldots \ldots$ & 9.40 & 9.20 & $\ldots \ldots$ & $\ldots \ldots$ & 9.30 & 9.76 \\
\hline $\mathrm{S}_{3}$ & 18.46 & 19.90 & 2.36 & 2.53 & 17.87 & 19.66 & 2.43 & 2.66 \\
\hline $\mathrm{S}_{4}$ & 18.90 & 20.13 & 3.70 & 3.40 & 20.26 & 20.33 & 4.16 & 4.43 \\
\hline $\mathrm{S}_{5}$ & 22.00 & 22.76 & 4.86 & 4.56 & 23.93 & 20.97 & 4.46 & 4.60 \\
\hline $\mathrm{F}-$ test & $*$ & $*$ & $*$ & $*$ & $*$ & $*$ & $*$ & $*$ \\
\hline LSD at 5\% & 2.55 & 1.80 & 1.90 & 1.15 & 1.87 & 1.84 & 1.54 & 1.14 \\
\hline
\end{tabular}

$*$ = significant at 0.05 probability level. $\mathrm{S}_{1}=$ pearl millet (pure stand), $\mathrm{S}_{2}=$ cow pea (pure stand), $\mathrm{S}_{3}=$ pearl millet : cow pea (side : side), $\mathrm{S}_{4}=$ pearl millet : cow pea (1 ridge : 1 ridge), $\mathrm{S}_{5}=$ pearl millet : cow pea $(2$ ridges : 2 ridges).

Table (7): Dry forage yield (ton /fed) of pearl millet and cow pea as influenced by intercropping systems at $1^{\text {st }}$ and $2^{\text {nd }}$ cuts in 2017 and 2018 seasons.

\begin{tabular}{|l|c|c|c|c|c|c|c|c|}
\hline \multirow{2}{*}{$\begin{array}{l}\text { Intercroppin } \\
\text { g }\end{array}$} & \multicolumn{9}{|c|}{ Dry forage yield (ton /fed) } \\
\cline { 2 - 9 } & \multicolumn{4}{|c|}{$1^{\text {st }}$ Cut } & \multicolumn{4}{c|}{$2^{\text {nd }}$ Cut } \\
\cline { 2 - 9 } & \multicolumn{2}{|c|}{ Pearl millet } & \multicolumn{2}{c|}{ Cow pea } & \multicolumn{2}{c|}{ Pearl millet } & \multicolumn{2}{c|}{ Cow pea } \\
\cline { 2 - 9 } & 2017 & 2018 & 2017 & 2018 & 2017 & 2018 & 2017 & 2018 \\
\hline $\mathrm{S}_{1}$ & 4.35 & 4.36 & $\ldots \ldots$ & $\ldots \ldots$ & 4.51 & 4.39 & $\ldots \ldots$ & $\ldots \ldots$ \\
\hline $\mathrm{S}_{2}$ & $\ldots \ldots$ & $\ldots \ldots$ & 1.38 & 1.40 & $\ldots \ldots$ & $\ldots \ldots$ & 1.46 & 1.41 \\
\hline $\mathrm{S}_{3}$ & 2.78 & 2.64 & 0.61 & 0.62 & 2.88 & 2.27 & 0.62 & 0.65 \\
\hline $\mathrm{S}_{4}$ & 2.65 & 2.67 & 0.50 & 0.64 & 3.13 & 2.55 & 0.63 & 0.66 \\
\hline $\mathrm{S}_{5}$ & 3.38 & 3.43 & 0.81 & 0.80 & 3.42 & 3.53 & 0.85 & 0.82 \\
\hline $\mathrm{F}$ - test & $*$ & $*$ & $*$ & $*$ & $*$ & $*$ & $*$ & $*$ \\
\hline LSD at 5\% & 0.56 & 0.57 & 0.20 & 0.14 & 0.41 & 0.43 & 0.19 & 0.09 \\
\hline
\end{tabular}

$*=$ significant at 0.05 probability level. $\mathrm{S}_{1}=$ pearl millet (pure stand), $\mathrm{S}_{2}=$ cow pea (pure stand), $\mathrm{S}_{3}=$ pearl millet : cow pea (side : side), $\mathrm{S}_{4}=$ pearl millet : cow pea (1 ridge : 1 ridge), $\mathrm{S}_{5}=$ pearl millet : cow pea $(2$ ridges : 2 ridges).

The intercropping systems of $S_{1}$ and $S_{2}$ as pure stand was superior in total fresh and dry forage yield (ton /fed) of pearl millet and cow pea, respectively. Followed by 2:2 ridges $\left(\mathrm{S}_{5}\right)$ at $1^{\text {st }}$ and $2^{\text {nd }}$ cuts in the both seasons. Total forage recorded (59.40 and 58.76 ton /fed) and (55.26 and 52.90 ton /fed) for total fresh forage yield and $(8.88$ and 8.75 ton /fed), (8.16 and 8.59 ton /fed) for total dry forage yield in the first and second seasons, respectively. These results are in agreement with those recorded by Abd El-Shafy (2002), Sharawy et al. (2011) and Hassan et al. (2017).

\subsection{Crude protein percentage}

Data presented in Table (9) showed that protein $\%$ of pearl millet was significantly affected by intercropping systems at $1^{\text {st }}$ and $2^{\text {nd }}$ cuts in 2017 and 2018 seasons. The intercropping system of 2:2 ridges $\left(\mathrm{S}_{5}\right)$ showed the highest 
mean values of protein $\%$ of pearl millet at $1^{\text {st }}$ and $2^{\text {nd }}$ cuts in the both seasons. But, protein $\%$ of cow pea showed no significant effects by intercropping systems at $1^{\text {st }}$ and $2^{\text {nd }}$ cuts in the both seasons. Whatever, the highest mean values of protein $\%$ of cow pea was obtained by pure stand $\left(\mathrm{S}_{5}\right)$ at $1^{\text {st }}$ and $2^{\text {nd }}$ cuts in the both season. The protein $\%$ of pearl millet may have improved by intercropping with legume cow pea due to availability of more nitrogen fixed by the legume cow pea. These results confirm the findings of Abd El-Shafy et al. (2009), Abusuwar and Bakshawain (2012) and Salem et al. (2019).

Table (8): Total fresh and dry forage yield (ton /fed) of pearl millet and cow pea as influenced by intercropping systems in 2017 and 2018 seasons.

\begin{tabular}{|l|c|c|c|c|}
\hline \multirow{2}{*}{ Intercropping } & \multicolumn{2}{|c|}{ Pearl millet } & \multicolumn{2}{c|}{ Cow pea } \\
\cline { 2 - 5 } Systems & 2017 & 2018 & 2017 & 2018 \\
\hline $\mathrm{S}_{1}$ & 59.40 & 58.76 & 8.88 & 8.75 \\
\hline $\mathrm{S}_{2}$ & 18.70 & 18.96 & 2.84 & 2.82 \\
\hline $\mathrm{S}_{3}$ & 40.60 & 44.76 & 6.91 & 6.19 \\
\hline $\mathrm{S}_{4}$ & 47.03 & 48.30 & 6.92 & 6.52 \\
\hline $\mathrm{S}_{5}$ & 55.26 & 52.90 & 8.16 & 8.59 \\
\hline $\mathrm{F}-$ test & $*$ & $*$ & $*$ & $*$ \\
\hline LSD at 5\% & 2.82 & 2.50 & 0.85 & 0.81 \\
\hline
\end{tabular}

$*$ = significant at 0.05 probability level. $\mathrm{S}_{1}=$ pearl millet (pure stand), $\mathrm{S}_{2}=$ cow pea (pure stand), $\mathrm{S}_{3}$ $=$ pearl millet : cow pea (side : side), $\mathrm{S}_{4}=$ pearl millet $:$ cow pea (1 ridge $: 1$ ridge), $\mathrm{S}_{5}=$ pearl millet : cow pea (2 ridges : 2 ridges).

Table (9): Protein (\%) of pearl millet and cow pea as influenced by intercropping systems at $1^{\text {st }}$ and $2^{\text {nd }}$ cuts in 2017 and 2018 seasons.

\begin{tabular}{|l|c|c|c|c|c|c|c|c|}
\hline \multirow{2}{*}{$\begin{array}{l}\text { Intercroppin } \\
\text { g }\end{array}$} \\
\cline { 2 - 10 }
\end{tabular}

$*=$ significant at 0.05 probability level. N.S = non-significant difference. $\mathrm{S}_{1}=$ pearl millet (pure stand), $\mathrm{S}_{2}=$ cow pea (pure stand), $S_{3}=$ pearl millet : cow pea (side : side), $S_{4}=$ pearl millet : cow pea (1 ridge : 1 ridge), $\mathrm{S}_{5}=$ pearl millet : cow pea (2 ridges : 2 ridges).

\subsection{Competitive relationships}

\subsubsection{Land equivalent ratio}

Data in Table (10) showed that land equivalent ratio (LER) was increased by intercropping cow pea with pearl millet in different systems during 2017 and 2018 seasons. The highest land 
equivalent ratio (LER) value was other two ridges, alternatively, using obtained by intercropping system of 2:2 planting distance of $20 \mathrm{~cm}(50 \%$ plant ridges $\left(\mathrm{S}_{5}\right)$ at planting pearl millet on population), with a seeding rate of 10 both sides of two ridges using planting $\mathrm{Kg} / \mathrm{fed}$. These results are in agreement distance of $20 \mathrm{~cm} \quad(50 \%$ plant with those obtained by Abd El-Lateef $e t$ population), with a seeding rate of 9 al. (2015), Hassan et al. (2017), Mahfouz $\mathrm{Kg} / \mathrm{fed}$, and cow pea on both sides of the et al. (2017) and Salem et al. (2019).

Table (10): Land equivalent ratio of pearl millet and cow pea as influenced by intercropping systems at $1^{\text {st }}$ and $2^{\text {nd }}$ cuts in 2017 and 2018 seasons.

\begin{tabular}{|c|c|c|c|c|c|c|c|c|c|c|c|c|}
\hline \multirow{4}{*}{$\begin{array}{l}\text { Intercropping } \\
\text { Systems }\end{array}$} & \multicolumn{12}{|c|}{ Land equivalent ratio (LER) } \\
\hline & \multicolumn{6}{|c|}{$1^{\text {st }} \mathrm{Cut}$} & \multicolumn{6}{|c|}{$2^{\text {nd }}$ Cut } \\
\hline & \multicolumn{3}{|c|}{2017} & \multicolumn{3}{|c|}{2018} & \multicolumn{3}{|c|}{2017} & \multicolumn{3}{|c|}{2018} \\
\hline & $\overline{\mathrm{L}_{\mathrm{m}}}$ & $\overline{\mathrm{L}_{\mathrm{C}}}$ & LER & $\overline{\mathrm{L}_{\mathrm{m}}}$ & $\mathrm{L}_{\mathrm{C}}$ & LER & $\overline{\mathrm{L}_{\mathrm{m}}}$ & $\mathrm{L}_{\mathrm{C}}$ & LER & $\overline{\mathrm{L}_{\mathrm{m}}}$ & $\mathrm{L}_{\mathrm{C}}$ & LER \\
\hline $\mathrm{S}_{3}$ & 0.637 & 0.440 & 1.077 & 0.607 & 0.443 & 1.050 & 0.637 & 0.423 & 1.060 & 0.517 & 0.463 & 0.980 \\
\hline $\mathrm{S}_{4}$ & 0.603 & 0.360 & 0.963 & 0.607 & 0.460 & $1 . \cdot 67$ & 0.690 & 0.433 & 1.123 & 0.573 & 0.467 & 1.040 \\
\hline $\mathrm{S}_{5}$ & 0.777 & 0.583 & 1.360 & 0.797 & 0.567 & $1.36^{\varepsilon}$ & 0.687 & 0.580 & 1.267 & 0.797 & 0.580 & $1.3^{\mathrm{VV}}$ \\
\hline
\end{tabular}

$\mathrm{L}_{\mathrm{m}}=$ LER millet, $\mathrm{L}_{\mathrm{C}}=$ LER cow pea, $\mathrm{LER}=\mathrm{L}_{\mathrm{m}}+\mathrm{L}_{\mathrm{C}} \cdot \mathrm{S}_{3}=$ pearl millet : cow pea (side : side), $\mathrm{S}{ }_{4}=$ pearl millet : cow pea (1 ridge : 1 ridge), $S_{5}=$ pearl millet : cow pea (2 ridges $: 2$ ridges).

\subsubsection{Relative crowding coefficient}

Recorded data in Table (11) showed that relative crowding coefficient (RCC) was also influenced by different treatments imposed in a similar trend as land equivalent ratio (LER) behavior during 2017 and 2018 seasons. The highest relative crowding coefficient (RCC) value was obtained by intercropping system of 2:2 ridges $\left(\mathrm{S}_{5}\right)$ at planting pearl millet on both sides of two ridges using planting distance of $20 \mathrm{~cm}(50 \%$ plant population), with a seeding rate of 9 $\mathrm{Kg} / \mathrm{fed}$, and cow pea on both sides of the other two ridges, alternatively, using planting distance of $20 \mathrm{~cm}(50 \%$ plant population), with a seeding rate of 10 $\mathrm{Kg} / \mathrm{fed}$. Similar results were obtained by Salem et al. (2019).

Table (11): Relative crowding coefficient of pearl millet and cow pea as influenced by intercropping systems at $1^{\text {st }}$ and $2^{\text {nd }}$ cuts in 2017 and 2018 seasons.

\begin{tabular}{|c|c|c|c|c|c|c|c|c|c|c|c|c|}
\hline \multirow{4}{*}{$\begin{array}{l}\text { Intercropping } \\
\text { Systems }\end{array}$} & \multicolumn{12}{|c|}{ Relative crowding coefficient (RCC) } \\
\hline & \multicolumn{6}{|c|}{$1^{\text {st }} \mathrm{Cut}$} & \multicolumn{6}{|c|}{$2^{\text {nd }} \mathrm{Cut}$} \\
\hline & \multicolumn{3}{|c|}{2017} & \multicolumn{3}{|c|}{2018} & \multicolumn{3}{|c|}{2017} & \multicolumn{3}{|c|}{2018} \\
\hline & $\mathrm{K}_{\mathrm{m}}$ & $\mathrm{K}_{\mathrm{c}}$ & RCC & $\mathrm{K}_{\mathrm{m}}$ & $\mathrm{K}_{\mathrm{c}}$ & RCC & $\mathrm{K}_{\mathrm{m}}$ & $\mathrm{K}_{\mathrm{c}}$ & RCC & $\mathrm{K}_{\mathrm{m}}$ & $\mathrm{K}_{\mathrm{c}}$ & RCC \\
\hline $\mathrm{S}_{3}$ & 1.770 & 0.792 & 1.401 & 1.534 & 0.794 & 1.217 & 1.766 & 0.738 & 1.303 & 1.070 & 0,855 & 0.914 \\
\hline $\mathrm{S}_{4}$ & 1.558 & 0.568 & 0.884 & 1.579 & 0.842 & 1.329 & 2.268 & 0.759 & 1.721 & 1.385 & 0.880 & 1.218 \\
\hline $\mathrm{S}_{5}$ & 3.384 & 1.421 & 4.808 & 3.688 & 1.333 & 4.916 & 2.221 & 1.393 & 3.093 & 4.104 & 1.389 & 5.700 \\
\hline
\end{tabular}

$\mathrm{K}_{\mathrm{m}}=$ Relative crowding coefficient for millet, $\mathrm{K}_{\mathrm{c}}=$ Relative crowding coefficient for cow pea. $\mathrm{S}_{3}=$ pearl millet : cow pea (side : side), $S_{4}=$ pearl millet : cow pea (1 ridge : 1 ridge), $S_{5}=$ pearl millet : cow pea (2 ridges $: 2$ ridges). 


\subsection{Aggressivity}

Recorded data in Table (12) indicated that in both growing seasons of this study, pearl millet was dominant crop at all intercropping systems. These results are in harmony with this reported by Mahfouz et al. (2017).

Table (12): Aggressivity of pearl millet and cow pea as influenced by intercropping systems at $1^{\text {st }}$ and $2^{\text {nd }}$ cuts in 2017 and 2018 seasons.

\begin{tabular}{|l|c|c|c|c|c|c|c|c|}
\hline \multirow{3}{*}{$\begin{array}{l}\text { Intercropping } \\
\text { Systems }\end{array}$} & \multicolumn{9}{|c|}{ Aggressivity (A) } \\
\cline { 2 - 9 } & \multicolumn{9}{|c|}{$1^{\text {st }}$ Cut } & \multicolumn{7}{c|}{$2^{\text {nd }}$ Cut } \\
\cline { 2 - 9 } & $\mathrm{A}_{\mathrm{m}}$ & $\mathrm{A}_{\mathrm{c}}$ & $\mathrm{A}_{\mathrm{m}}$ & $\mathrm{A}_{\mathrm{c}}$ & $\mathrm{A}_{\mathrm{m}}$ & $\mathrm{A}_{\mathrm{c}}$ & $\mathrm{A}_{\mathrm{m}}$ & $\mathrm{A}_{\mathrm{c}}$ \\
\cline { 2 - 10 } & 0.098 & -0.098 & 0.081 & -0.081 & 0.107 & -0.107 & 0.028 & -0.028 \\
\hline $\mathrm{S}_{3}$ & 0.123 & -0.123 & 0.078 & -0.078 & 0.132 & -0.132 & 0.056 & -0.056 \\
\hline $\mathrm{S}_{4}$ & 0.093 & -0.093 & 0.108 & -0.108 & 0.053 & -0.053 & 0.112 & -0.112 \\
\hline $\mathrm{S}_{5}$ & &
\end{tabular}

$A_{m}=$ Aggressivity for millet, $A_{c}=$ Aggressivity for cow pea. $S_{3}=$ pearl millet $:$ cow pea (side $:$ side), $S_{4}=$ pearl millet : cow pea (1 ridge : 1 ridge), $S_{5}=$ pearl millet : cow pea ( 2 ridges $: 2$ ridges).

\section{Conclusion}

From the previous results of intercropping systems under this study, planting pearl millet on both sides of two ridges using planting distance of $20 \mathrm{~cm}(50 \%$ plant population), with a seeding rate of 9 $\mathrm{Kg} / \mathrm{fed}(\mathrm{fed}=\mathrm{Acre})$, and cow pea on both sides of the other two ridges, alternatively, using planting distance of $20 \mathrm{~cm}$ (50\% plant population), with a seeding rate of $10 \mathrm{Kg} / \mathrm{fed}$, (2:2 ridges) could be concluded that to obtain the best forage yield, quality and increasing land equivalent ratio in summer season under the same conditions of this study.

\section{References}

A.O.A.C. (1980), Official Method of Analysis of the Association of Official Agriculture Chemists, $13^{\text {th }}$ Ed., AOAC, Washington, DC., USA.

Abd El-Lateef, E. M., Abd El-Salam, M.
S., El-Habbasha, S. F. and Ahmed, M. A. (2015), "Effect of maize cow pea intercropping on light interception, yield and land use efficiency", International JournalChemTech Research, Vol. 8 No. 6, pp. 556-564.

Abd El-Shafy, A. S. (2002), "Intercropping teosint with guar under different plant population densities", Fayoum Journal Agricultural and Development, Vol. 16 No. 2, pp. 91-97.

Abd El-Shafy, A. S., Tarrad, M. M. and. Fahmy, A. H. (2009), "Effect off intercropping patterns of teosint with cow pes on yield, quality and their competitive relationships", Annals of Agriculturel Science Moshtohor, Vol. 47 No. 3, pp. 215-224.

Abdoul karim, T. D., Sanoussi, A., Maarouhi, I. M., Yacoubou, B. and Mahamane, S. (2016), "Effect of plant density and genotypes of cow 
pea (Vigna unguiculata (L.) Walp) on the growth and yield of millet (Pennisetum glaucum (L.) R. Br.)", ARPN Journal of Agricultural and Biological Science, Vol. 11, No. 6, pp. 242-247.

Abusuwar, A. O. and Bakshawain, A. A. (2012), "Effect of chemical fertilizers on yield and nutritive value of intercropped sudsn grass (Sorghum sudanense) and cow pea (Vigna unguiculata L. Walp) forage grown in an adverse environment of western Saudia Arabia", African Journal of Microbiology Research, Vol. 6 No. 14, pp. 3485-3491.

Ayub, M., Tanveer, A., Nadeem, M. A. and Shah, S. M. A. (2004), "Studies on the fodder yield and quality of sorghum grown alone and in mizture with rice bean", Pakistan Journal of Life and Social Sciences, Vol. 2 No. 1, pp. 46-48.

Black, C. A. (1965), Methods of soil analysis, Soil Science Society of America Inc. Publisher, Madison, Wisconsin, U.S.A.

Dahmardeh, M. A., Ghanbbari, B. S. and Ramroudi, M. (2009), "Effect of intercropping maize with coe pea on green forage yield and quality evaluation", Asian Journal of Plant Sciences, Vol. 8, No. 3, pp. 235239.

De Wit, C. T. (1960), "On Competition", Verslagen Landbouwkundige Onderzoekigen, Vol. 66, pp. 1-82.
El-Sarag, E. I. (2013), "Cow pea sorghum mixtures as affected by water stress levels and forage mixing ratio in semi-arid regions", World Journal of Agricultural Sciences, Vol. 9 No. 4, pp. 325-334.

Freed, R. Einensmith, S. P. Gutez, S. Reicosky, D. Smail, V. W. and Wolberg, P. (1989), User's Guide to MSTAT-C Analysis of Agronomic Research Experiments, Michigan State University, East Lansing, USA

Gawad, A. M. A., Seif, A. S. and Bashir, M. I. (1991), Effect of intercropping patterns of forage cow pea with two types of grain sorghum on growth, yield and quality, International Desert Development Conference, Cairo, Egypt, pp. 407-421.

Girase, P. P., Sonawane, P. D. and Wadile, S. C. (2007), "Effect of pearl millet (Pennisetum glaucum) based intercropping system on yield and economics of pearl millet on shallow soils under rainfed conditions", International Journal of Agricultural Sciences, Vol. 3 No. 2, pp. 192-193.

Gomez, K. A. and Gomez, A. A. (1984), Statistical procedures for agricultural research, John Willy and Sons Inc., New York, USA.

Hamd Alla, W. A., Shalaby, E. M., Dawood, R. A. and Zohry, A. A. (2014), "Effect of cow pea (Vigna sinensis L.) with maize (Zea mays L.) intercropping on yield and its 
components", International Journal of Biological, Veterinary, Agricultural and Food Engineering, Vol. 8 No. 11, pp. 1170-1176.

Hassan, H. H. M., Sayed, M. R. I. and Mousa, W. M. E. (2017), "Effect of intercropping patterns on forage yield and land use efficiency of some summer fodder crops", Zagazig Journal of Agricultural Research, Vol. 44 No. 6A, pp. 2007-2020.

Ibrahim, M., Ayub, M., Tanveer, A. and Yaseen, M. (2012), "Forage quality of maize and legumes as monocultures and mixtures at different seed ratios", Journal of Animal and Plant Sciences, Vol. 22, No. 4, pp. 987-992.

Jackson, M. L. (1973), Soil Chemical Analysis, Prentice Hall of India Pvt. Ltd., New Delhi, India, pp. 498.

Johanson, R. E. (1967), "Comparison of methods for estimating cotton leaf area", Agronomy Journal, Vol. 1 No, 3, pp. 73-79.

Mahfouz, S. A., Mohamed, M. A., Atteya, A. K. G. and Ibrahim, M. E. (2017), "Impact of intercropping system on yield and quality of Lolium multiflorum and Trigonella foenum-graecum L.", International Journal of Pharmaceutical and Clinical Research, Vol. 9 No. 4, pp. 324-331.

Mc-Gilchrist, C. A. (1965), "Analysis of competition experiments",
Biometrics, Vol. 1, pp. 975-985.

Olsen, S. R. and Sommers, L. E. (1982), "Phosphorus", In: Methods of soil analysis, Part 2, second edition (editors: Page, A. L. Miller, R. H. and Keeney, D. R.), Agronomy Series No. 9, American Society of Agronomy, Madison, Wisconsin, U.S.A., pp. 403-430.

Refay, Y. A., Alderfasi, A. A., Selim, M. M. and Awad, K. (2013), "Evaluation of variety, cropping pattern and plant density on growth and yield production of grain sorghum - cow pea under limited water supply condition growth, yield and yield component characters of sorghum", Journal of Agriculture and Veterinary Science, Vol. 2 No. 3, pp. 24-29.

Salem, A. Kh., Sultan, F. M. and ElDouby, K. A. (2019), "Intercropping cowpea (Vigna unguiculata L.) with teosinte (Zea mexicana Schrad) on forage yield productivity and its quality", Egypt Journal of Agronomy, Vol. 41 No. 2, pp. 183196.

Shahin, M. G., Abdrabou, R. Th., Abdelmoemn, W. R. and Hamada, M. M. (2013), "Response of growth and forage yield of pearl millet (Pennisetum glaucum) to nitrogen fertilization rattes and cutting height", Annals of Agricultural Sciences, Vol. 58, No. 2, pp. 153162.

Sharawy, W. M., Helmy, A. A. and Abd 
El-Shafy, A. S. (2011), "Intercropping teosint with cow pea or guar and their effects on forage yield, quality and competitive relationships", Egypt Journal of Applied Sciences, Vol. 26 No. 4, pp. 284-295.

Sherief, A. E. and Said, E. M. (1999), "Effect of intercropping patterns and seeding rates on forage yield productivity and competition parameters of sorghum and cow pea", Journal of Agriculture Sciences Mansoura University, Vol. 24 No. 2, pp. 385-397.

Stickler, F. C., Wearden, S. and Pauli, A. W. (1961). "Leaf area determination in grain sorghum", Agronomy Journal, Vol. 53, pp. 187-188.

Suryawanshi, P. K., Deore, S. M., Patel, M. R. and Sadhu, A.C. (2014), "Production potential of forage maize (Zea mays L.) - cow pea (Vigna unguiculata L.) intercropping system as influenced by row ratios", Asian Resonance, Vol. 3, pp. 97-99.
Willey, R. W. (1979), "Intercropping its importance and research needs 1 . Competition and yield advantage and 2. Agronomy and research approaches", Field Crop Abstracts, Vol. 3, pp. 97-99.

Zeidan, E. M., Ramadan, L. E., Gomaa, M. A. and Hassan, H. H. M. (2003), "Effect of sowing, mixture pattern and cutting date on forage yield productivity of fodder maize, cow pea and guar", Zagazig Journal of Agricultural Research, Vol. 30 No. 4, pp. 1311-1326. 